\title{
Exploring the challenges of the Iranian parliament about passing laws for resource allocation in healthcare: a qualitative study
}

\author{
Seyed Ramezan Mohsenpour ${ }^{1}$, Mohammad Arab ${ }^{1}$, Seyed Hasan Emami Razavi ${ }^{2}$, Ali Akbari Sari ${ }^{1}$
}

${ }^{1}$ Department of Health Management and Economics, School of Public Health, Tehran University of Medical Sciences, Tehran, Iran

${ }^{2}$ Department of Surgery, Cancer Institute, Tehran University of Medical Sciences, Tehran, Iran

\section{Type of article: Original}

\begin{abstract}
Background: Awareness about the process of law making and the factors that affect the legislative process have an important role in improving legislations that are approved by parliaments.

Objective: This study aimed to explore and analyze the process of development and enactment of law in Iran's parliament, and factors that might affect the enactment of laws that are related to the allocation and distribution of health sector resources in Iran.

Methods: In this case study, data were collected through review of literature and national documents, and experts' interviews. Interviews were performed with selected members of parliament (MPs), ex members of parliament and professionals from the Ministry of Health and Medical Education (MOHME) (15 persons). MAX QDA 10 was used for coding and constructing themes. Data were analyzed in five steps (familiarization, developing a conceptual framework, coding, indexing, and interpretation) using a content analysis with inductive and deductive approaches.

Results: The main factors that could affect the approval and enactment of legislations related to allocation of healthcare resources in the Iranian parliament were categorized in seven themes including: Importance of issue, resource availability, legislator's awareness about the topic, lobbying and unofficial relations with influential officials, mentioning strong reasons by MOHME, weakness of previous laws, and positive feedback related to the same laws.

Conclusion: Although the process of law making in parliament, and implementation of them in health organizations have legal stages, the study showed that several key factors affect this trend. In fact, it is suggested the health policy makers and MPs consider extending a range of factors to improve the process of law making and the efficiency of legislation related to allocation of healthcare resources.

Keywords: Legislation, Resource allocation, Healthcare, Parliament, Iran
\end{abstract}

\section{Introduction}

Health systems are responsible for healthcare provision through efficient use of scarce resources (1). This essential task requires a series of prerequisites including efficient and sustainable resources and appropriate resource allocation laws and mechanisms (2). Achieving the health system goal and meeting the health needs of the population, health professionals and policy makers should be familiar with the law making process in the cabinet and the parliament (3). Furthermore, health managers should be aware of legal capacities and the approval process, promulgation and monitoring of the implementation in the distribution of health system resources (4). In other words, such insight compels managers and health policy makers to be sensitive to any weakness in the law, any need to revise the law making process and inadequate financial resources to promote society's health; and immediately address the problem through legal solutions (5). Almost, everyone knows the importance of awareness about laws

\section{Corresponding author:}

Dr. Ali Akbari Sari, Department of Health Management and Economics, School of Public Health, Tehran University of Medical Sciences, Tehran, Iran. Tel.: +98.2188989128, Fax:+98.2188989129, Email: Akbarisari@tums.ac.ir Received: May 16, 2017, Accepted: July 25, 2017, Published: October 2017 iThenticate screening: July 19, 2017, English editing: September 02, 2017, Quality control: September 02, 2017 This article has been reviewed / commented by five experts

(C) 2017 The Authors. This is an open access article under the terms of the Creative Commons Attribution-NonCommercialNoDerivs License, which permits use and distribution in any medium, provided the original work is properly cited, the use is non-commercial and no modifications or adaptations are made. 
and the process of its enactment, either in governmental offices or non-governmental health care centers (6). Finding strengths and weaknesses of law making in the current situation of the country, factors that influence their enactment and avoiding enactment of a law in the health sector, and degree of legislator's attention to the health sector seem to be necessary (2). In addition, because one of the main prerequisite of establishing equity in health is the distribution of resources based on rational principles and the needs of different regions of the country, the special attention of policy makers and other key decision makers is crucial in different levels of decision making, to achieving fair and proportionate distribution of scarce resources (7). In this section, we will describe the law approval and enactment process in the Iranian Parliament: In Iran, the law approval and enactment contains three steps, and after passing these steps the proposal will be a law and must be implemented: Proposing the bill, Signing the law, and Promulgation.

\subsection{Proposing the bill}

The cabinet and the parliament can enact a law separately. If the cabinet proposed it, then it is a "bill". According to Article 74 of the constitution "the bill after confirmation of the cabinet will be proposed to parliament" (8). The legislators with considering the population needs, may feel the necessity of a law and propose it for enactment. In legal terminology, it is called a "Bill" (Tarh in Persian). According to Article 74 of the constitution: "for proposing a bill to parliament at least 15 legislators must sign it" (8). According to Article 94 of the constitution, all enactments of parliament must be sent to the council that is called "The Guardian Council of the Constitution" (GCC). This council will investigate the enacted laws of parliament in terms of matching with Islamic codes and constitution. Confirmation of this council is necessary.

\subsection{Signing the law}

After approval of a law in parliament and confirmation of GCC, its implementation must be signed by the president. The president must sign the enactments of parliament after passing legal steps and promulgate them to officers.

\subsection{Promulgation}

The aim of promulgation is to inform all people about the law. Article 2 of the Civil Law says: "after 15 days of the promulgation of a law in the country, it must be implemented, unless there is no special mechanisms for its implementation"(9). Our search showed that no study has examined the process of legislation related to health resources. Therefore, this study aimed to identify the factors that affect the enactment of laws related to the distribution of health sector resources, for a good understanding of the current situation.

\section{Material and Methods}

This case study was done based on three data sources including literature review, national health related documents review and key informants (expert participants that had enough information and experience about the study topic) interviews from January to September 2016 in Iran. Relevant national documents and web sites were selected through a review of the literature and consulting policy makers. A combination of key terms such as legislation, law, healthcare, parliament and health system were used in the search. We searched in PubMed, Scopus, Cochrane library, and google scholar to find relevant studies. To increase the comprehensiveness of literature search we scanned reference lists of papers. Landmark papers were also identified based on the number of citations obtained in databases such as Web of Science. Some sources were hand searched to identify the main legislations that were signed and enacted by Iranian parliament from 2005 to 2016 and were related to the financing and allocation of healthcare resources. Selected laws were the fifth and sixth cultural, economic and social development plans of the country, as well as health related enacted laws, including annual budgets from 2005 to 2016, and other laws that are related to resource distribution within the health sector. To achieve in-depth understanding about the process of developing selected laws and to ensure the comprehensiveness of the data, 15 face-to-face semi-structured interviews were conducted with members of parliament (MPs), ex MPs and experts from various sectors (Table 1). The topic guide of interview included the main questions about the budget supervision process in parliament and MOHME, the formula of resource allocation in the macro level, the methods of MPs participation in the resource allocation decisions, the implementation process of budget law in the MOHME and other health related organizations. We used a purposive and snowball sampling method to identify individuals from the health system and related organizations with at least 5 years direct experience in the field of resource allocation and prioritizing (Table 1). Interviewees were first contacted via email or telephone and if they agreed to be interviewed, a time was set for a face-to-face interview. The interviews were carried out through a semi-structured guide and by a member of the study team (S.R.M) in the interviewee's office. The literature review was used for developing the topic guide. The minimum time of interviews was 30 minutes, the maximum time was 90 minutes and the average length of 
interviews was 50 minutes. After data were saturated, the interviews were stopped. In other words, in the 13th interview, we reached some same and repeated descriptions, so based on authors' agreement, the 15th interview was the last interview. Interviews were transcribed into texts and reviewed several times. In order to increase the trustworthiness of the study, about 10 percent of interview codes were checked by a second person and, after ensuring consensus, the coding and theme extraction were continued. The second person was a Ph.D. candidate of health policy that had experience regarding qualitative studies. Open coding was employed. After coding the first 7 interviews, the main themes were identified and in the 15th interview, due to the data saturation, interviews were stopped. MAX QDA10 was used for initial categorizing the codes and themes. Interviews and documents were analyzed through content analysis. Finally, using a content analysis, and in five steps (familiarization, developing a conceptual framework, coding, indexing, and interpretation), using inductive and deductive approaches, the data were categorized and analyzed (10). Validity was ensured in three ways. First, diverse data sources were applied including the documents, literature, and interviews, which allowed for triangulation. Second, respondents from different organizations participated in the interviews. Third, themes were developed by all authors to control probable biases. This study was approved by the ethics committee of Tehran University of Medical Sciences (Approval Code: 9111434001). The goal of study was presented to interviewees and the interviews were conducted and recorded after obtaining their verbal consent. Also, we ensured the interviewees about the confidentiality of information.

Table 1. Characteristics of Interviewees

\begin{tabular}{|c|c|c|c|c|c|c|c|}
\hline \multirow[t]{2}{*}{ Organization } & \multirow{2}{*}{$\begin{array}{l}\text { Number of } \\
\text { interviewees }\end{array}$} & \multicolumn{2}{|l|}{ Sex } & \multicolumn{2}{|c|}{ Age (year) } & \multicolumn{2}{|l|}{ Education } \\
\hline & & $\begin{array}{l}\text { Male } \\
(\%)\end{array}$ & $\begin{array}{l}\text { Female } \\
(\%)\end{array}$ & $>50$ & $<50$ & $\begin{array}{l}\text { Medical related } \\
\text { education }\end{array}$ & $\begin{array}{l}\text { Non-Medical } \\
\text { education }\end{array}$ \\
\hline MOHME & 3 & 100 & 0 & 2 & 1 & 3 & 0 \\
\hline Health commission of the parliament & 5 & 100 & 0 & 4 & 1 & 3 & 2 \\
\hline $\begin{array}{l}\text { Management committee of medical } \\
\text { universities }\end{array}$ & 2 & 100 & 0 & 2 & 0 & 2 & 0 \\
\hline $\begin{array}{l}\text { Deputy of strategic planning of } \\
\text { presidency }\end{array}$ & 2 & 100 & 0 & 1 & 1 & 1 & 1 \\
\hline $\begin{array}{l}\text { General Inspection Organization of } \\
\text { Iran }\end{array}$ & 2 & 100 & 0 & 1 & 1 & 1 & 1 \\
\hline Research center of the parliament & 1 & 100 & 0 & 1 & 0 & 1 & 0 \\
\hline Sum & 15 & 100 & 0 & 11 & 4 & 11 & 4 \\
\hline
\end{tabular}

\section{Results}

The selected laws that were related to the allocation of healthcare resources are presented in Table 2. The factors that could affect the process and law making and enactment of these laws in parliament were identified and analyzed in seven themes (Table 3). They are described in the following.

Table 2. Selected laws related to the healthcare resource allocation

\begin{tabular}{|l|l|l|}
\hline ID & Title of the law & Content of the law \\
\hline 1 & $\begin{array}{l}\text { Fourth economic and } \\
\text { social development } \\
\text { plan of the country: }\end{array}$ & $\begin{array}{l}\text { Clause 50 - d The government must allocate a special financial credit in addition to regular } \\
\text { credits, as a temporary fund for supporting students of higher education institutions in non- } \\
\text { governmental and non-profit institutions which have been accepted by the Ministry of Science, } \\
\text { Research and Technology (MOSRT), and MOHME but do not have any student welfare fund. } \\
\text { These funds give long-term loans with zero interest rate to the students. The students must pay } \\
\text { back the loan in long-term installments after graduation (18). }\end{array}$ \\
\hline 2 & $\begin{array}{l}\text { The fifth economic } \\
\text { and social } \\
\text { development plan }\end{array}$ & $\begin{array}{l}\text { Clause 224 m } \\
\text { Paragraph 2- The excess special revenue of universities and higher educational and research } \\
\text { institutions which have been registered by the council of the expansion of higher level education } \\
\text { of MOSRT and MOHME or in other legal organizations will be reallocated to the organization } \\
\text { which has acquired the revenue (18). }\end{array}$ \\
\hline 3 & $\begin{array}{l}\text { The budget plan of } \\
\text { 2005 }\end{array}$ & $\begin{array}{l}\text { Note 14 - health } \\
\text { a) For implementation of universal insurance coverage, enacted on November 23, 2004, } \\
\text { MOHME, with the approval of the Management and Planning Organization (MPO) can change } \\
\text { the developed budget (i.e. increasing or decreasing the maximum level of each item according } \\
\text { to enacted budget maximally by 30 percent), so that the maximum needed facilities will be } \\
\text { available for the implementation of the law, without any interruption in the ordinary activities of } \\
\text { healthcare and educational centers (19). }\end{array}$ \\
\hline
\end{tabular}




\begin{tabular}{|c|c|c|}
\hline 4 & $\begin{array}{l}\text { The budget plan of } \\
2006\end{array}$ & $\begin{array}{l}\text { Note } 14 \text { and - five percent of applied research funds of MOHME and related organization must } \\
\text { be allocated to basic and clinical researches for improving the health level of chemical and } \\
\text { mental disorder veterans (19). }\end{array}$ \\
\hline 5 & $\begin{array}{l}\text { The Budget plan of } \\
2007\end{array}$ & $\begin{array}{l}\text { Note } 14 \text { d- allows MOHME to: } \\
\text { Compliance with standards that are related to registration of each medicine or their raw material } \\
\text { by external -firms or their branch in Iran and registration of factories that produce cosmetics and } \\
\text { food or raw materials and medical and laboratory equipment by external firms or their agents in } \\
\text { Iran, for registration of each mentioned product, } 54 \text { million Rials and } 9 \text { million Rials, } \\
\text { respectively, will be received and deposited in a special revenue account that belongs to this } \\
\text { law, issue } 140104 \text { part three of the law (19). }\end{array}$ \\
\hline 6 & $\begin{array}{l}\text { The budget plan of } \\
2008\end{array}$ & $\begin{array}{l}\text { One thousand two hundred billion Rials of funds from part 22, row 550,000 from table } 9 \text {, } \\
\text { allocates to welfare funds of MOSRT, MOHME, and Azad University to give loans to students } \\
\text { for their tuition payments, with zero interest rate. The installments will begin after graduation } \\
\text { (19). }\end{array}$ \\
\hline 7 & The budget of 2009 & $\begin{array}{l}\text { MOHME have to pay } 1.6 \text { times of the confirmed tariff for the patients' treatment and costs of } \\
\text { inpatient beds from public resources and funds of Article } 9 \text { row 550,000 to medical universities } \\
\text { based on each hospital's performance, in addition to } 100 \text { percent of hospital's revenue. These } \\
\text { hospitals will not receive any other funds from public resources (19). }\end{array}$ \\
\hline 8 & $\begin{array}{l}\text { The budget plan of } \\
2010\end{array}$ & $\begin{array}{l}\text { 7-In } 2010 \text { the salary and job benefits of contract personnel of MOHME based on maximum } \\
\text { payment to government employees on February } 18,2010 \text { is equal to other contractual and long- } \\
\text { term employees, through clause (V) Note (19) of the budget plan of } 2007 \text {, developed by the } \\
\text { Ministry of Financial Affairs. }\end{array}$ \\
\hline 9 & $\begin{array}{l}\text { The budget plan of } \\
2011\end{array}$ & $\begin{array}{l}\text { 2- By increasing revenue from increased exports of oil and liquid gases in excess of what is } \\
\text { mentioned in clause (1) of this law, before depositing currencies in sovereign wealth fund, the } \\
\text { equivalence of these amounts after going to the treasury will be allocated to: } \\
\text { B } 3 \text { billion dollars to the health sector (MOHME) for implementation of goals that are } \\
\text { mentioned in clause b of article } 34 \text { of the fifth development plan (19). }\end{array}$ \\
\hline 10 & Budget plan of 2012 & $\begin{array}{l}\text { 15- All health insurance organizations were required to pay } 60 \% \text { of received bills from } \\
\text { contracted health care providers and hospitals before investigation of their claims maximally in } \\
\text { two weeks, and the other part must be paid maximally in the next three months. If the insurance } \\
\text { organization does not comply, it has to compensate the losses of providers and hospitals with a } \\
15 \% \text { interest rate (19). }\end{array}$ \\
\hline 11 & $\begin{array}{l}\text { The budget plan of } \\
2013\end{array}$ & $\begin{array}{l}\text { 37-government is required to allocate } 8 \text { billion Rials, from selling government's share in } \\
\text { governmental firms, for developing and implementation of Hadi plan (a public plan for } \\
\text { developing rural areas) and prioritized projects, including improving the environment of rural } \\
\text { areas, building and maintenance of rural roads, rural water supply, building health houses, and } \\
\text { promoting rural sports, according to development indicator of each city (19). }\end{array}$ \\
\hline 12 & $\begin{array}{l}\text { The budget plan of } \\
2014\end{array}$ & $\begin{array}{l}\text { Note } 8 \\
\text { J- The tariffs on imported cars increase equivalent to five percent of car's price on the ship } \\
\text { (FOP). The revenue from this source deposit in national treasury and equivalent to } 1500 \text { billion } \\
\text { Rials will be allocated to buy ambulances for MOHME (19). }\end{array}$ \\
\hline 13 & $\begin{array}{l}\text { The budget plan of } \\
2015\end{array}$ & $\begin{array}{l}\text { The MPO is required to allocate the funds of research centers and institutions affiliated with } \\
\text { universities and ministries which have a budget row in this law only on the basis of related } \\
\text { university or ministry recommendations in three month intervals, proportionate to their revenue } \\
\text { and with considering the cap (19) }\end{array}$ \\
\hline 14 & $\begin{array}{l}\text { The budget plan of } \\
2016\end{array}$ & $\begin{array}{l}\text { Note } 9 \text { clause a- Universities, higher education institutions, and science and technology parks } \\
\text { are allowed to take loans from banks, maximally equivalent to their revenue of the previous } \\
\text { year (2015), to complete their capital asset plans, and installments should be paid through their } \\
\text { revenues (19). }\end{array}$ \\
\hline
\end{tabular}

Table 3. The themes that were identified from findings

\begin{tabular}{|l|l|}
\hline ID & Theme \\
\hline 1 & Importance of issue \\
\hline 2 & Availability of resources \\
\hline 3 & The awareness of the parliament members about the issue \\
\hline 4 & Lobbying \\
\hline 5 & Suggesting strong reasons by MOHME \\
\hline 6 & Weakness of previous laws \\
\hline 7 & Positive feedback of similar laws \\
\hline
\end{tabular}




\subsection{Importance of issue}

The importance and necessity of the issue is one of the factors that influences proposing a subject for enactment in parliament. Sometimes, parliament members feel the necessity of a law through society's need, and negative impacts of hesitation in satisfying that need. Also, sometimes the cabinet puts a subject on the agenda and proposes it to parliament. Moreover, the frequency and the number of raising an issue by society also have an important role in proposing a subject to be a law. One member of parliament that had valuable experience about parliament actions and law enactment said: Interview number 14: .... You know parliament members are the voice of the people so they try to present the main problems and issues that are affecting the lives of the pubic.... According to the opinion of the interviewees, scarcity of resources is always a major challenge of health systems and their revenues is usually less than the costs. Therefore, the laws that are related to health resource distribution are one of the main enactments of parliament. Interviewees believed the issue of resource allocation in this sector is a Damocles sword, on the one side the health of people and on the other side resource limitation. Some of them said that some ministries look at the MOHME only as a consumer, which create costs, so they take more caution and might have hesitation to allocate resources to this ministry. An interviewee from MOHME who was an executive officer in a general hospital said: Interviewee number 3: “.... other ministers think that MOHME only creates costs, then they are not willing to help this ministry" .......

\subsection{Availability of resources}

Based on the opinions of the interviewees, one of the influential factors of enactment of laws in parliament or the GCC is the availability of resources. If the required funds are not provided or there is no plan for providing it in the future, then GCC will reject it, and the parliament must revise the plan even if the enacted law is crucial and parliament and the cabinet have confirmed it. Experts commented that sometimes, for implementation of a law, resources are shifted from one plan to another. They however, believed that it is accepted in situations that do not result in inequality and spending public money on unnecessary affairs. According to interviewees, sometimes a law is enacted based on unstable resources, and after a short time it stops or the speed of its implementation becomes slow. The recent Health Transformation Plan (HTP) is one of them, which, because of unstable financial resources and lack of scientific support, its implementation speed has been reduced over time.

\subsection{The awareness of the parliament members about the issue}

According to interviewees, awareness of parliament members that know different aspects of the issue is one of the necessities of enactment of a law that matched with society's needs. Health related issues need a health-center perspective and awareness about different aspects of society's health. Based on claims of interviewees, parliament members can be categorized into three groups in terms of how they decide about the enactment of a law: individuals that independently investigate the issue and study about its different aspects, individuals that consult with experts, and individuals that decide according to their subjective judgments. Some interviewees believed that some of the enactments of parliament are the results of the lack of an adequate and comprehensive investigation of parliament members which led to a waste of resources. For example, according to an article in the second development plan, a series of hospitals were built in areas that had no efficiency, and faced patients with some challenges in access. A member of the Deputy of Strategic Planning of Presidency said: “....25 years ago, an article was appealed in parliament that really did not have scientific base, I think acceptance of such law shows that members of parliament did not involve themselves in the decision-making process actively .... "Another important issue is that during recent years, the research center of parliament was established to increase the necessity of proposed laws. This center, based on the importance of the issue, performs a precise investigation, and then presents its recommendation to parliament. The more important point is that the opinions and the degree of experience and awareness of members of the health commission of parliament have a great impact on health-related decisions, especially laws that are related to resource distribution.

\subsection{Lobbying}

Based on the interviewee's opinions, two of the factors that can affect parliament decisions are lobbying and/or unofficial relations with powerful authorities. Although developing the budget for different sectors is based on predetermined formula and indicators, some interviewees believed that relationships with senior officials of the parliament and MOHME managers often lead to more budget for MOHME. One MP who was recently the hospital manager in the public hospital said: Interviewee number 10: “......... unfortunately, with a glance, it can be understood that there is not an expert's opinion behind the MOHME budget, and lobby and relationships have the upper hand in budget allocation to this field, of course, this method is not appropriate or stable......" Interviewees believed that limited resources and budget restrictions of the health sector are the main reasons that force managers 
to lobby. Indeed, the association with the dominant political party of the country is one of the main leverages for budget allocation to medical universities, so that sometimes, due to political pressures and not real need, a hospital or health care center had been built in a region that had no resulting benefit and was a waste of resources. It should be noted that lobbying is a common and emphasized phenomenon in some countries.

\subsection{Suggesting strong reasons by MOHME}

Interviewees believed that the existence of skilled experts in MOHME and expressing the necessity of laws which are related to the resource distribution in a precise manner has a great impact on enactment of intended proposals, the budget allocation can be justified in this way and would be practice based. According to the claims of some interviewees providing evidence and expressing the necessity of a law can make strong it, even in the situations that resources are not sufficient. Some parliament members mentioned that: "....early years of Islamic revolution and war with Iraq that despites severe resource limitations; plans such as primary health care network, and national vaccination became implemented because of compassionate experts in MOHME.... ". On the other hand, providing a firm and defendable reasons by MOHME officials, especially the minister, can be influential.

\subsection{Weakness of previous laws}

One of the factors that can influence the development and enactment of the proposals is the weakness of previous laws or lack of suitable laws on the intended issue. Interviewees believed that sometimes a law that is enacted, require other complementary laws, this provides the context for the development and enactment of more complete laws. Also, sometimes despite the need to suitable regulations, there are gaps in implementation of some affairs. A member of insurance organization said: ".....Sometime a law is necessary but the organizations perform it in a wrong way so this results the unwillingness of parliament members to enactment the similar laws and regulations in the future!!!!!.... "Some items of the health sector budget are ambiguous and making them clear is a necessity for the next year budgets, some interviewees believed. Also, in some laws that are related to human resources of the health sector, the way that these resources must be financed are not mentioned, which leads to stopped or temporary implementation.

\subsection{Positive feedback of similar laws}

According to claims of interviewees, sometimes the good results of implementation of some laws, especially in the health sector, leads to enactment of similar laws in parliament or its completion to achieve optimal results. For example, one interviewee said that, according to the healthcare network law at provincial level (that was enacted during the war with Iraq) each province was allowed to build in a health center in each city, but useful and unpredicted results in the first year of implementation led policy makers to allow provinces to build health centers in more cities. Some pundits believed that accurate development and precise planning of laws that were related to the health sector budget in the years after war led to enactment of similar laws and ideal use of laws and, hence, promotion of health indicators of the country.

\section{Discussion}

The health sector has the responsibility of providing public health to society, and to do this requires sufficient and stable resources. The aim of this study was to identify the process of enactment of laws related to financing and allocation of healthcare resources and factors that can influence this process in the Iranian parliament. The laws that are related to resource distribution, must be enacted by the highest legislative organization of the country. While it seems that there is a particular trend for proposing and enactment of laws, this study shows that different factors affect the process of enactment. What is certain is that these laws are related to different institutions and processes, and only a particular institution or process is not engaged in their formation. The importance of the issue is factors that show the necessity of issue from the perspective of offers, but this may be unknown to the parliament members. Thus, what is important here is the strong reasons of MOHME, that is, the experts of this institution must support the proposal through citing strong and firm scientific evidence, this should be based on the current situation of the country, and be able to provide required explanations and logics for MOHME as the main supporter of patients and citizens in parliament, so the minister and other officials will have an informative and strong defense. Although in other countries the enactment of financial laws, such as budget plans, has a defined trend, failure to provide adequate reasoning by the authorities leads to rejection of law (11). The impacts of provided reasons by the MOHME is to the extent that even if parliament members are not aware about the subject, if the minister provides sufficient explanation about the subject, there is a hope to attract the trust and attention of the parliament members. Lack of awareness of the parliament members is a subject that has more importance, and maybe a proposed law becomes rejected just because of this issue. Therefore, it seems that the research center of parliament can act as an 
informative entity to inform legislators and for making decisions based on evidence. Of course, the existence of this center does not mean that legislators need to acquire information and knowledge about different subjects, rather, this can be said that this center acts as a supportive and certain source of information. Parliament members should update their information about important issues of society, including health related subjects, and prioritizing and distribution of resources in this sector.This study shows that with the inadequate knowledge of legislators about the proposed subjects to parliament, laws will be enacted that not only fail to address current problems but will increase the necessity of proposing complementary laws. Of course, on the other side, there are laws that because of their efficiency and positive outcomes on health status of the country, will lead to enactment of similar laws. Indeed, enacted laws have unpredicted consequences whose importance is not less than intended short term outcomes. This important point indicates that enactment of each law provides a basis for enactment or rejection of other laws.

Lobbying and association with powerful sources is another factor that can affect enactment of laws that are related to the health sector. This study shows that sometimes health sector managers, for enacting a proposal, resort to associations with key decision makers' and, hence, influence the decision-making process in parliament. Of course the main incentive of these actions is to gather more resources to satisfy population need in the health sector, but sometimes enactment of such laws weakens the justice spirit of legislation. Although during the past three decades the lobbying theories have a slow growth, up to now two different approaches have been introduced (12). The first approach considers lobbying as a form of trade-off. The second one introduced it as a kind of incentive activity. Both of them are looking for mechanisms for changing preferences and wishes of legislators about policies (13) In addition, lobbying has some expansive aspects in Europe and especially in the USA, and lobbies as strength activists have important influences on health system reforms or whether a macro plan of the health sector is implemented (14). A good example of this issue relates to the advertisements and negotiations of lobbies in Congress and television programs and the failure of the Clinton health plan in 1995 (15). The opposition groups of this reform through lobbying and expending a lot of money in public media failed the enactment of the intended program. The existence of such associations, acts as the facilitator of obtaining extra budgets or before the due date. Moreover, this association with the legislators often leads to acquiring resources by using informal methods. Although receiving extra resources and expending them for patients appears to be a good idea, continuing this trend leads to the exclusion of some universities and hospitals from needed resources and the promotion of unethical behavior at different levels of the health system, and is an unstable and faulty process. Tourani and colleagues investigated political associations and lobbying as effective factors in decisions that are related to prioritization in the health sector (16). Lobbying exists in many countries, especially in the health sector of them. The importance of this issue is somehow that in 1995 the Lobbying Disclosure Act became enacted and required all groups and individuals that are engaged in lobbying to introduce their activities (12). The more important point is that most of the time lobbies in the health sector of Iran are mainly related to hospitals not primary care networks. Similarly, in the USA, activists of diseases and public health organizations spend less on lobbying compared with other health related groups, and hence, have less impact on policy making. In contrast, general practitioners and other specialists spend a lot on lobbying (17). On one hand, although failure of key policy makers of the health system to comply with the principles of modern management to generate extra resources and make organizations more active, and resorting to lobbying and political factions can be considered as a short-term solution to address some problems of provider organizations, in the long-term, not only will it not be useful for an organization but it will make innovations and dynamic performances weak. On the other hand, lack of accurate planning based on an epidemiological map of the country led to allocation of hospitals and providers in regions that did not even have primary conditions of intended services. It seems that in the current situation of the health system and with regard to lack of enough resources for providing most of key treatment services in some regions of the country, such decisions lead to a waste of resources and people's skepticism about future decisions of the health system.

According to the findings of this study; availability of resources is one of the most important factors that can affect the enactment of laws in the health sector. Sometimes a law becomes rejected because of inadequate resources in the health sector, despite sufficient supportive information. Interestingly, it seems that the proposed bills of government have more chances of using available resources compared with those proposed by parliament, hence, have more chance to be approved by GCC. Indeed, government experts, because of their knowledge about financial and nonfinancial resources that are achievable, propose bills in a manner that, contingent upon their required financial resources, are greatly secured. The important issue is the stability of predicted financial resources for the implementation of the law and if stable resources are not predicted, the implementation of the law in the long-term will face challenges and it will be stopped after a while. The study had some limitations. First, some of interviewees did not have enough information about our study and this undoubtedly affected our findings. Second, although we 
searched various sources, we did not find enough papers and studies for discussion and comparison. Third, the number of interviewees was limited and this can affect the generalization of the findings.

\section{Conclusions}

The study showed that the process of law making, especially laws that are related to the allocation of healthcare resources, is complex and multifactorial and is influenced by a wide range of actors. Awareness of law makers and policy makers can improve this process and the laws that are approved and enacted, and this can subsequently lead to improved allocation of resources. In other words, although the process of law making in parliament and implementation of them in health organizations have legal stages, the study showed that several key factors affect this trend. In fact, the health policy makers and MPs should consider to extend the range of factors to improve the process of law making and the efficiency of legislation related to allocation of healthcare resources. It seems that the health committee of parliament has an important role in improving this awareness and also prioritization of resources. It is also suggested that lobbies should be transparent in their activities and appropriate punishments should be considered for their unreported activities.

\section{Acknowledgments:}

This paper is part of a Ph.D. thesis that was conducted by Seyed Ramezan Mohsenpour and was supported by School of Public Health, Tehran University of Medical Sciences (TUMS registration number $=9111434001)$.

\section{Conflict of Interest:}

One of the authors was recently a consultant of the Minister for Health and the first author was recently a parliamentary deputy of the Minister for Health.

\section{Authors' contributions:}

All authors contributed to this project and article equally. All authors read and approved the final manuscript.

\section{References:}

1) Kapiriri L, Norheim OF, Heggenhougen K. Using burden of disease information for health planning in developing countries: the experience from Uganda. Soc Sci Med. 2003; 56(12): 2433-41. PMID: 12742606.

2) Landwehr C, Klinnert D. Value congruence in health care priority setting: social values, institutions and decisions in three countries. Health Econ Policy Law. 2015; 10(02): 113-32. doi: 10.1017/S1744133114000437. PMID: 25434454.

3) Rubinstein A, Pichon-Riviere A, Augustovski F. Development and implementation of health technology assessment in Argentina: Two steps forward and one step back. Int J Technol Assess Health Care. 2009; 25(S1): 260-9. doi: 10.1017/S0266462309090734. PMID: 19527545.

4) Abstracts from the Society for Clinical Trials Annual Meeting, Miami, May 21-23, 2012. Clinical Trials. 2012; 9(4): 450-554. doi: 10.1177/1740774512453224.

5) Defechereux T, Paolucci F, Mirelman A, Youngkong S, Botten G, Hagen TP, et al. Health care priority setting in Norway a multicriteria decision analysis. BMC Health Serv Res. 2012; 12: 39. doi: 10.1186/1472-6963-12-39. PMID: 22335815, PMCID: PMC3312861.

6) Waldau S, Lindholm L, Wiechel AH. Priority setting in practice: Participants opinions on vertical and horizontal priority setting for reallocation. Health policy. 2010; 96(3): 245-54. doi: 10.1016/j.healthpol.2010.02.007.

7) Gibson JL, Martin DK, Singer PA. Priority setting in hospitals: Fairness, inclusiveness, and the problem of institutional power differences. Soc Sci Med. 2005; 61(11): 2355-62. doi: 10.1016/j.socscimed.2005.04.037. PMID: 15950347.

8) Iranian Constitution. Available from: http://www.iranonline.com/iran/iraninfo/government/constitution.htm.

9) Government of Islamic Republic of Iran. Civil Service Management Law. Media portal of Government of Islamic Republic of Iran. Available from: http://www.dolat.ir

10) Tuckett AG. Qualitative research sampling: the very real complexities. Nurse Res. 2004; 12(1): 47-61. doi: 10.7748/nr2004.07.12.1.47.c5930. PMID: 15493214.

11) Miller GJ, Robbins D. Progressive Government Budgeting. Handbook of Governmental Accounting. 2008: 71.

12) Landers SH, Sehgal AR. Health care lobbying in the United States. Am J Med. 2004; 116(7): 474-7. doi: 10.1016/j.amjmed.2003.10.037. PMID: 15047037. 
13) Terry V. Lobbying: Fantasy, reality or both? A health care public policy case study. Journal of Public Affairs. 2001; 1(3): 266-80. doi: 10.1002/pa.72.

14) West DM, Heith D, Goodwin C. Harry and Louise go to Washington: political advertising and health care reform. J Health Polit Policy Law. 1996; 21(1): 35-68. doi: 10.1215/03616878-21-1-35. PMID: 8708342.

15) Tourani S, Maleki MR, Hadian M, Amiresmaili MR. A survey on present status of health services priority setting in Iran. Payesh. 2011; 2: 217-30.

16) Davies E. How big is the US healthcare lobby? BMJ. 2013; 347: f7366. doi: 10.1136/bmj.f7366. PMID: 24336003.

17) Parliament of Islamic Republic of Iran. The budget plan of 2005, Parliament of Islamic Republic of Iran, August 18, 2015. Available from: http://hbi.ir

18) Islamic Parliament Research Center. The budget plan of 2014, Islamic Parliament Research Center of The Islamic Republic Of IRAN, Available from: http://rc.majlis.ir/fa. 